\title{
Inner structure and kinematics of the Sushchany-Perga fault zone of the Ukrainian Shield according to the tectonophysical study
}

\begin{abstract}
S.V. Mychak, L.V. Farfuliak, 2021
S.I. Subbotin Institute of Geophysics of the National Academy of Sciences of Ukraine, Kiev, Ukraine

Received July 29, 2020

The field tectonophysical works were carried out in the upper reaches of the Ubort River basin along the Zolnia-Maidan-Kopischany fault. The research aim was determination of the inner structure and kinematics of the Sushchany-Perga fault zone of the western pfrt of the Ukrainian Shield. For investigation of fracturing and structural-textural elements of rocks the structural-paragenetic method of tectonophysics was used. It was determined that formation of the Sushchany-Perga fault zone continued during at least five phases of deformation. They were accompanied by the formation of differently oriented shear zones: Khmelivka, Sushchany, Perga, Rudnia-Khochin, Lopatychi. The Khmelivka and Sushchany shear zones are similar to striking of the Nemyriv and Khmelnik fault zones of the Ukrainian shield, which belong to the Nemyriv stage of faulting $(\sim 1.99 \mathrm{Ga})$. The Rudnia-Khochin and Perga phases are related to the fact that the Sushchany-Perga fault zone was quite active during the junction of the Fennoscandia and Sarmatia microplates. We have established that the development of thrust fault and normal down throw fault type shears, which took place in an area of compression and extension, respectively, is associated with the formation period of the Perga granitoids complex $(1.80-1.70 \mathrm{Ga})$. This alternation of the compression and extension conditions has led to formation of the ore occurrences and deposits within the Perga tectonic joint. This investigation found that the Sushchany-Perga fault zone arose in the Late Paleoproterozoic at the Nemirov stage of fracture formation, simultaneously with Goryn, Lutsk, Teteriv and Nemyriv fault zones as a result of the junction of two ancient microplates - Fennoscandia and Sarmatia.
\end{abstract}

Key words: Ukrainian Shield, Sushchany-Perga fault zone, Perga tectonic joint, structural- and-textural elements, deformations, stress fields.

Introduction. The main results of tectonophysical studies of the Sushchany-Perga fault zone (SP) are presented in this article. It is situated on the northwestern part of the Ukrainian Shield (US) and separate Volyn Domain (VD) from Osnytsk-Mikashevichi igneous belt (OMIB).

The SP fault zone separates granitoids of the Zhytomyr (2.06-2.08 Ga) and Osnytsk $(1.99 \mathrm{Ga})$ complexes deforming them as a sinistral strike - slip fault and uplifting the Tamoshgorod dyke (1.79 Ga) as a dextral srike - slip fault type [Gintov, 2014]. On the modern stage of investagations, SP fault zone is considered as one of the fault zones that was formed at the Nemyriv stage of faulting in the Late Paleoproterozoic, simultaneously with Goryn, Lutsk, Teteriv and Nemyriv fault zones, due to the junction of two ancient microcontinents - Fennoscandia and Sarmatia [Bogdanova et al., 1996, 2013; Gintov, Pashkevich, 2010; Mychak, 2016; Gintov et al., 2018] (Fig. 1).

SP fault zone has been known since the beginning of the last century due to the presence of a unique rare metal mineralization. Science the 1920s, it was studied by M.I. Bezborodko, V.I. Luchitsky and L.G. Tkachuk. In the 194090s, I.I. Gurvich, N.A. Bezpalko, L.S. Galetsky, L.B. Zubkov, S.V. Metallidi, S.V. Nechaev, 


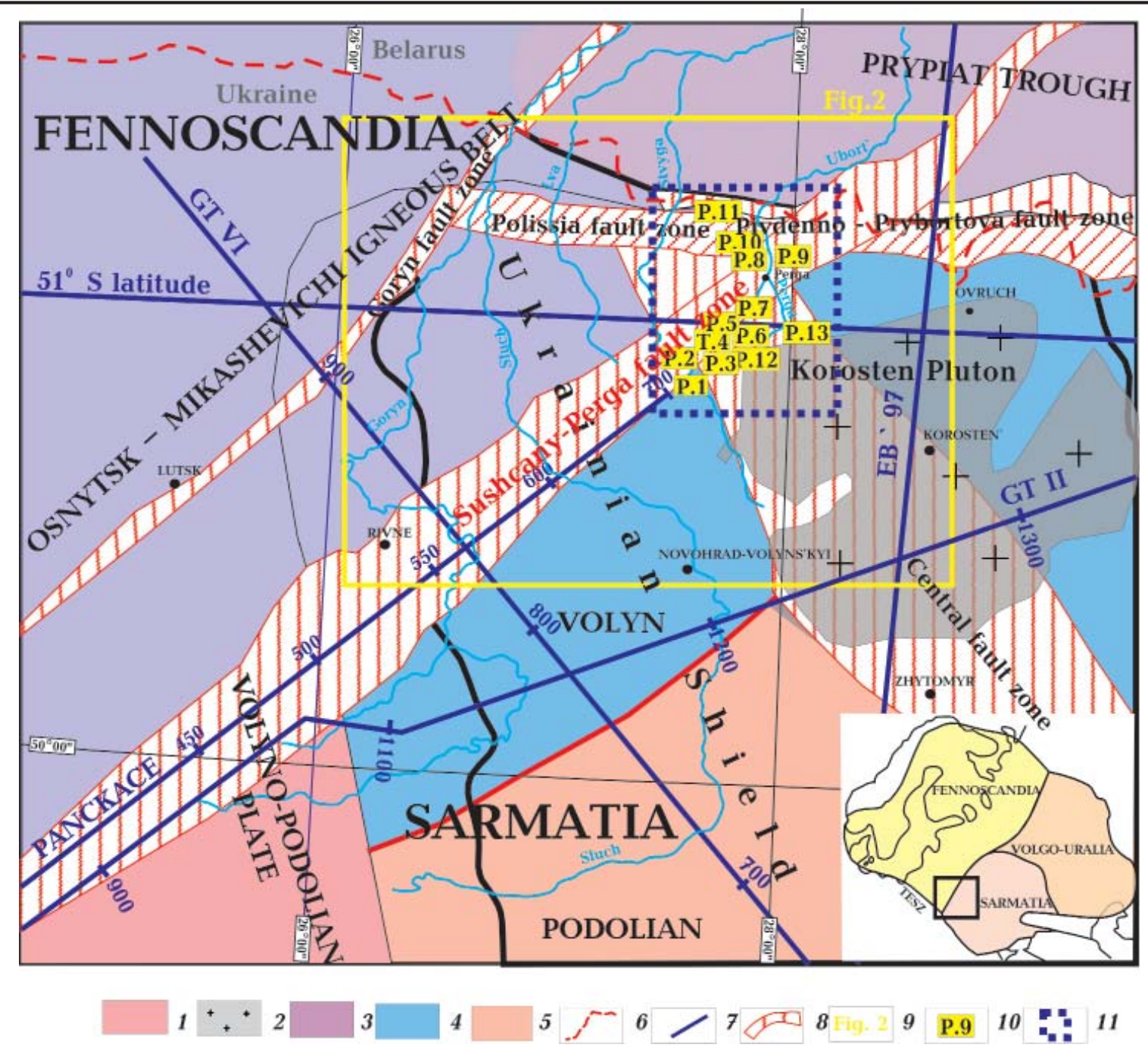

Fig. 1. Tectonic sketch of the main tectonic units of the Fennoscandia and Sarmatia crystalline basement [modified after Krylov, 1988, Starostenko et al., 2018]. The inset map to the right down shows the subdivision of the East European Craton into the three segments: Fennoscandia, Sarmatia and Volgo-Uralia [Bogdanova, 1993]. Paleoproterozoic crust: 1 - East European craton (Ukrainian Shield, KP - Korosten pluton), Volyno-Podolian plate, Prypiat Trought; $2-1.80-1.75$ Ga Korosten pluton (KP), anorthosite - mangerite — charnockite-granite plutons; $3-2.0-1.95$ Ga Osnytsk-Mikashevichi Igneous belt; $4-2.2-2.1$ Ga Volyn and Ros domains. Archean crust: 5- 3.7-3.8 Ga Podolian domain. Others: 6 - Ukrainian border, 7 - Seismic profiles: EUROBRIDGE'97 (EB '97), PANCAKE, VI and II geotraverses (GT VI and GT II); seismotomographic crossection along 51 $00^{\circ}$ southern latitude; 8 - fault zones; 9 - position of the Fig. 2 - geological scheme of the crystalline basement of the western part of the Ukrainian Shield; 10 - the points of the field work in the Perga tectonic joint; 11 - research area.

A.G. Marchenko and others studied metallogeny and mapped this zone. In this period SP fault zone was studied by gravimetric (scale is 1:200 000-1:50 000) and aero-, land magnetic (scale is 1:50 000-1:10 000) methods (O.L. Polivanchuk, V.M. Egorov, O.V. Teslenko, V.I. Starostenko, M.P. Koryak etc.).

Due to geophysical data SP fault zone has been traced to the south-west and north-east along its all length by almost $300 \mathrm{~km}$. Detailed geological studies were concentrated mainly in the Perga tectonic joint (PTJ) (Fig. 2). It is associated with the main metallogenic prospects of the region and formed as a result of intense tectonic activation, magmatism and metasomatic rocks substitution [Ponomarenko et al., 2017].

Geological and geophysical setting. The SP fault zone is up to $3 \mathrm{~km}$ of width on the flanks and up to 8-10 km of width in the mid- 


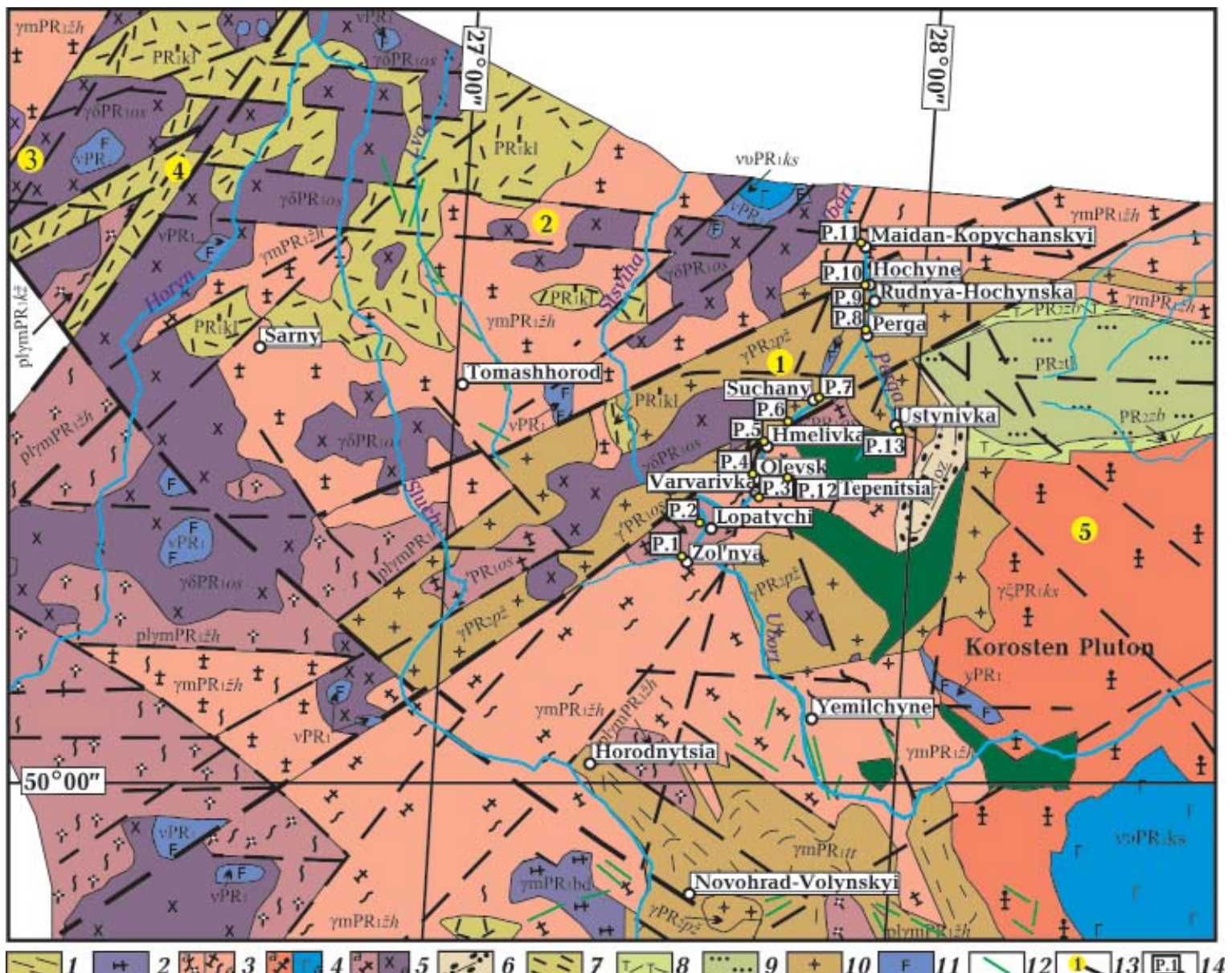

Fig. 2. Geological scheme of the crystalline basement of the NW part of the Ukrainian Shield scale is 1:1 000000 (modified from [Scherbak, Volodin, 1984]): 1 - gneisses of the Teteriv series; 2 - granitoids of the Berdychiv complex; 3 - Zhytomyr complex ( $a$ - plagiogranites; $b$ - migmatites); 4 - Korosten complex ( $a$ - gabbro anarthosites; $b$ - rapakivi granites); 5 - Osnytsk complex ( $a$ - plagiogranites; $b$ - migmatites); 6 - sedimentary rocks of the Ozeriany suite of the Pugachivka series; 7 - volcanic rocks of the Klesiv series; 8 - rhyolites of the Zbrankiv suite of the Ovruch series; 9 - quartzites of the Tovkachiv suite of the Ovruch series; 10 - granites of the Perga complex; 11 - gabbroids; 12 - dyke complex; 13 - fault zones (numbers in circles): 1 - SushchanyPerga, 2 - Polissia, 3 - Horyn, 4 - Lutsk, 5 - Central; 14 - pleaces of the field tectonophysical works carried out within the Perga tectonic joint.

dle part and trends in $50^{\circ} \mathrm{NE}$ direction within the US at a distance of $\sim 150 \mathrm{~km}$. Within the open part of the Ukrainian Shield, geologists have identified several differently oriented elementary faults (in tectonphysical terminology - shear zones) - Khochyn, Yastrubets, Golovny, Southern, Sushchany, Ustynivka, Yurivka, Ubort, Perga, Plotnytsk [Romanyuk, 2013; Ponomarenko et al., 2017]. The shear zones of various orientations are considered to be originated during long time in the different tectonic stress fields [Gintov et al., 2017].

The SP fault zone intersects the Polissya and Central fault zones of the NW ori- entation (see Fig. 1, 2), fragments of which are traced in the SE direction through the Korosten pluton to the Kocheriv fault zone agree with [Metalidi, Nechaev, 1983], and further to the SE through Rosyn Domain, connecting with the Lelekiv fault zone of the Ingul Domain [Mychak, 2015].

The OMIB belongs to the Fennoscandian segment of the East European Craton, and the other tectonic units are included in the Sarmatian segment (see Fig. 1) [Bogdanova, 1993; Bogdanova et al., 2008]. The NE orientated OMIB is located in the northern part of the study region, where metamorphosed 


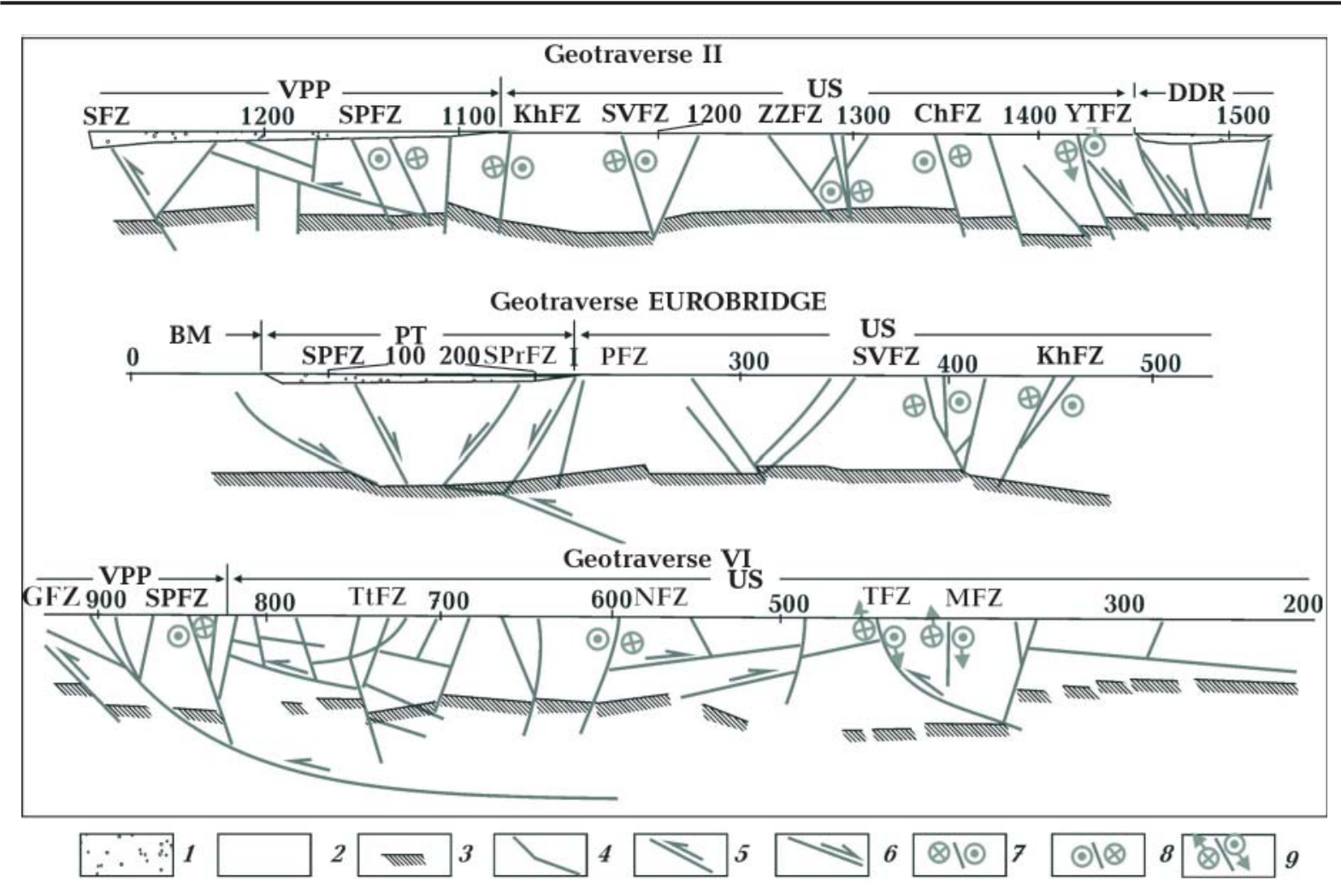

Fig. 3. Kinematic characteristics of the main fault zones along the seismic profiles: II and VI DSS geotaverses and WARR EB` 97 profile [Gintov, 2019]: 1 - sedimentary cover, 2 - crystalline rocks of the earth crust, 3 - Moho surface, 4 - fault zones, 5-9- kinematic signs (5 - thrust fault, normal fault, underthrust fault, 6 - reverse fault, 7 - dextral strike - slip fault, 8 - sinistral strike - slip fault, 9 - reverse or normal strike - slip fault (depending on the slope of the zone). Regions: VPP — Volyno-Podolian plate, US — Ukrainian shield, DDR Dnieper-Donetsk Rift, BM — Belarusian massif, PT — Pripiat trough. Fault zones: SFZ — Stokhodsk, SPFZ — Sushany-Perga, KhFZ — Khmelnyk, SVFZ — Sarny-Varvarivka, ZZFZ — Zvizdal-Zaliska, ChFZ — Chernobyl, YDFZ — Yadliv-Traktemyriv, SPFZ — South Pripyat, PFZ — Polissia, GFZ — Goryn, TtFZ — Teteriv, NFZ - Nemyriv, TFZ - Talnivka, MFZ — Moldovka.

sedimentary and volcanic Palaeoproterozoic rocks were intruded by many bodies of granodiorites - diorites in the period 2.0-1.95 Ga.

The other three domains: Volyn, Podolian and Ros are related to the Ukrainian Shield. The Podolian domain (PD) is the oldest block in the region where rocks of granulitic metamorphic grade mafic granulites and pyroxene-bearing gneisses of the Archean age (3.4-2.6 Ga) are exposed among Palaeoroterozoic granitoids of different composition. This domain represents the oldest stage of evolution of the continental crust with formation of the Archean granulitic cores [Chekunov, 1989]. The Volyn domain (VD), located between the PD and the OMIB includes mostly gneiss formations of the Teteriv complex of amphibolitic metamorphic grade with gra- nitic intrusions of the Zhytomyr complex with an age of 2.06 Ga [Shcherbak et al., 1998]. Subsequent fault activation, accompanied by anorogenic magmatic activity, represented by intrusions of various compositions, from peridotites to granodiorites, is caused by tectonic events occurring within the limits of the OMIB. As a result of a successive stage of tectonic stabilization of the craton, terminated by a second episode of anorogenic magmatism (1.8-1.73 Ga), the large, complex Korosten Pluton (KP), composed of rapakivi granites and anorthosites, was formed. At the platform stage, the domain was covered by sedimentary and volcanic rocks. The Ros domain, located in the southeastern part of the region, is made of sedimentary and volcanic rocks subjected to amphibolites grade of meta- 


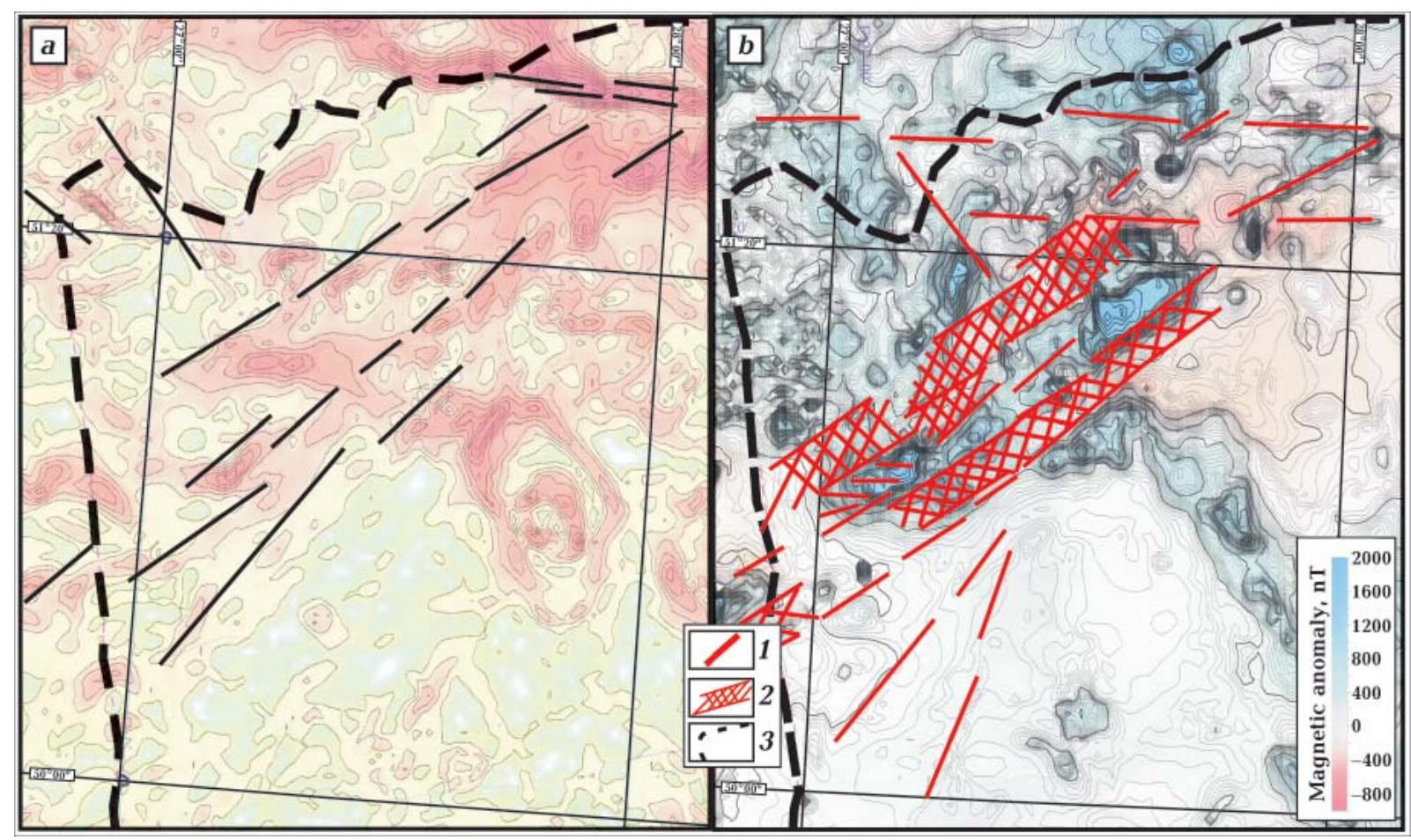

Fig. 4. Geophysical fields of the Sushchany-Perga fault zone [Yentin et al., 2002\}. Scale is 1:500 000: $a$ - residual gravity anomalies $\partial g$ (Suxova - Nigard formula, $R=8 \mathrm{~km}, r=1 \mathrm{~km}$ ); $b$ - anomalous magnetic field (isodines $\mathrm{Z}_{\mathrm{a}}$ and $\left.\Delta T_{a}\right) ; 1$ - echeloned shears; 2 - shear zones; 3 - contour of US.

morphism (amphibole-bearing and biotite gneisses, plagiogneisses and amphibolites).

The SP fault zone is bounded by granitoids of the Osnytsk complex with bodies of subsilicic rocks and persilicic volcanic outliers of the Klesiv series on the NW. Granitoids of the Zhytomyr complex and gneisses of the Teteriv series, as well as (on the north) quartzite-sandstones of the Ovruch series are developed from the SE (see Fig. 2).

Granitoids of the Zhytomyr and Osnytsk complexes deformed to mylonites and blastomylonites are also developed in the zone itself. In the northeastern part, at the intersection with the WE Trending Polissia fault zone, within the Perga tectonic joint, metasomatically and dynamometamorphically altered granites of the Perga complex. Structural and textural features of these granites are developed, among which the following varieties are distinguished: Khochyn, Ustyniv, Perga, Lviv, Yastrub, as well as aplites, vein granites and metasomatites [Metallides, Nechaev, 1983; Gintov, 2005; Kostenko, 2010], which differ mainly in grain size and variations of textural features.

In the study region, SP fault zone was studied by Soviet deep seismic sounding (DSS) and modern wide-angle reflection/refraction (WARR) methods. Here, field researches are carried out at different times. The deep structure of this region is defined by II and VI DSS profiles [Ilchenko, 1985; Sollogub, 1986, 1988; Sollogub et al., 1988], modern WARR deep seismic researches PANCKAKE [Staroctenko et al., 2013], EUROBRIDGE 97 profiles [Thybo et al., 2003] and seismotomographic crossection along $51^{\circ} 00^{\prime}$ southern latitude [The creation ..., 2006].

We are mainly interested in the reflectors isolated on the $\mathrm{P}$ and $\mathrm{S}$ waves, according to which it is possible to trace the depth of the SP fault zone and the earth crust structure.

The SP fault zone crosses the Moho surface on the all three profiles (Fig. 3). On the EUROBRIDGE profile, the SP fault zone reaches the surface of the crystalline basement under the Prypiat Trough, crossing the Moho surface 
and dipping in the mantle. On the geotraverse VI, SP fault zone crosses Moho, connecting with the surface of Fennoscandia and Sarmatia subduction zone and goes to a $100 \mathrm{~km}$ depth, and according to seismotomography its depth reaches $300-400 \mathrm{~km}$ [Gintov, 2019].

From NW to SE VI geotraverse crosses OMIB, VD, PD and the SP fault zone (see Fig. 1). SP and Horyn fault zones dipping to the SE and can be traced to the Moho surface at a depth of $55 \mathrm{~km}$ in the obtained section [Ilchenko, 1985; Sollogub, 1986, 1988]. It was reinterpreted the seismic materials and constructed a seismic tomographic model along the VI line of geotraverse that made it possible to clarify the earth crust structure in the vicinity of SP fault zone [Lysynchuk et al., 2019, 2020]. At the profile distances between the PC 900 - 840 in terms of the velocity structure (within the velocity values of 5.0 to $6.0 \mathrm{~km} / \mathrm{s}$ ) we can observe a trough down to the depth of $15 \mathrm{~km}$ which corresponds to the trough of the OMIB with the Paleoproterozoic crust. The OMIB is separated from the structure of the US by the Goryn and Sushchany-Perga fault zones. Further to the southeast, along the section line, we can observe velocity uplifts in the Earth's crust within the Ukrainian Shield, corresponding to the main tectonic domains. E.g. between PC 840-750, at the depth of $30 \mathrm{~km}$ and below, from the $7.0 \mathrm{~km} / \mathrm{s}$ isoline of the lower crust top, there is a rise up to the surface with the speed of $5.0 \mathrm{~km} / \mathrm{s}$ corresponding to the Volyn Domain. The Moho is located here at the depth of $45 \mathrm{~km}$. In the Podolian Domain between 750 - 620 pickets, velocity uplift is marked at the depth of $25 \mathrm{~km}$ from the velocity isoline of $7.0 \mathrm{~km} / \mathrm{s}$ in lower crust up to the surface at PC 650 with a velocity of $5.25 \mathrm{~km} / \mathrm{s}$. The upper crust of the Volyn block lies at depths of $7-21 \mathrm{~km}$, the middle crust - at depths of $20-35 \mathrm{~km}$, and the surface of Moho lies at a depth of 45-50 km [Lysynchuk et al., 2020].

Geotraverse II [Sollogub et al., 1988] is sub-parallel and close to the PANCAKE profile (see Fig. 1) [Staroctenko et al., 2013]. It allows us to consider the structure of the SP fault zone along its central part and across the main domains of the study area: Volyno-Po- dolian plate and Volyn Domain of the western slope of the US. According to the PANCKAKE section data, a thick layer of the upper crust lies at a depth of $25 \mathrm{~km}$. It includes low velocity lenses (with $V_{P} \sim 6.1 \mathrm{~km} / \mathrm{s}$ ) at depths of $12-18 \mathrm{~km}$ and $15-18 \mathrm{~km}$ respectively, which traced to the Carpathians and marks at depths of $12-18 \mathrm{~km}$ within the VD and PD on the EB'97too. The middle crust has a thickness of $\sim 9 \mathrm{~km}$ in depth ranges from $20-25 \mathrm{~km}$ to $27-33 \mathrm{~km}$. The lower crustal layer (down to Moho at $44-48 \mathrm{~km}$ depth) has a high velocity with $V_{P}=7.2 \div 7.4 \mathrm{~km} / \mathrm{s}$.

The EB' 97 profile crosses SP fault zone in the crossing point of the Pivdenno-Prybortova, Polissia fault zones on the northern slope of the Ukrainian Shield between Korosten pluton and Prypiat trough (see Fig. 1). EB'97 gives a clear seismic reflection of subduction markers of structures and traced under Moho. This is recognized in [Ilchenko, 2002; Thybo et al., 2003], where a two-dimensional inversion of the travel time of seismic waves was performed. In [Bogdanova et al., 2006] these data are supplemented by density modeling using the dependences of density on the velocities of $P$ - and $S$-waves, as well as data from petrology and other geological data.

The seismotomographic crossection along $51^{\circ} 00^{\prime} \mathrm{S}$ latitude also confirms the existence of the dipping of Fennoscandia under Sarmatia, which is traced to the upper mantle [Gintov, 2019] and the formation of a boundary between the ancient microplates by Gorin and Sushchany-Perga fault zones in the earth's crust. Section along $51^{\circ} 00^{\prime}$ S latitude compiled by I.K. Pashkevich et al. [The creation..., 2006] intersects OMIB, Volyn Domain and Korosten Pluton. It crosses of the SP fault zone in the area of its intersection with the Central fault zone of the Ukrainian Shield (see Fig. 1). The Central fault zone was traced to a surface of the $50 \mathrm{~km}$ depth and dipping to the SE. Seismotomography data indicate a sloping depression of the relatively high-velocity lithosphere of the SW edge of the East European Craton under the relatively low-velocity lithosphere of adjacent plates [Gintov, Pashkevich, 2010].

Thus, according to the seismic data giv- 
en above, the SP fault zone was formed as a result of the activation of the joint zone of Fennoscandia and Sarmatia. The SP and Horyn faults zone separate OMIB from the US structure. Moho depths below the OMIB increase to $50 \mathrm{~km}$ and more, whereas the average depths beneath the PD and VD are about $45 \mathrm{~km}$. The PT and KP are outlined by a Moho uplift to a depth of $35-37 \mathrm{~km}$.

According to geophysical data [Gintov, 2005], the SP fault zone is traced to NE to the Prypiat trought, and SW in the VolynoPodolian plate basement and continues as the Kremenets fault zone. The zone is quite well manifested in gravity and magnetic fields. It is most clearly fixed by the large gravity step of the NE orientation (Fig. 4, a). It limits the most intense Rokytnia gravity maximum in the SE that is located outside the study area.

Gravity step associated with SP fault zone. It has a width of up to $8 \mathrm{~km}$, amplitude of up to $10-18 \mathrm{mGal}$ and extends from the $\mathrm{N}$ boundary of the US (near the Perga town to the Ostrog town) and further SW toward the Precarpathian trought. Several (2-3) localized linear anomalies are clearly traced on the residual gravity anomaly map $\partial g$, which correspond to some shear zones of SP fault zone.

In the magnetic field, the SP fault zone is characterized by the alternation of linear positive and negative anomalies in Fig. $4, b$. Positive anomalies can be traced over the rocks of the Osnytsia complex with striped volcanic bodies and intrusions of the subsilicic rocks. Negative anomalies correspond to bands of tectonites and granitoids of the Zhytomyr complex. The nature of the increased gradients of the magnetic field indicates a dip of the SP fault zone in the NW direction in the average $50^{\circ}$ to $80^{\circ}$ angle at the $\mathrm{SE}$ edges of the positive anomaly.

Methods. Tectonophysical studies of the SP fault zone were started in 1985 by O.B. Gintov, V.M. Isai, V.B. Kobylyansky, P.V. Bilychenko. The works were performed by the Gzovsky-Stoyanov structural-paragenetic method. Plastic (brittle-ductile) deformations of rocks were studied by measuring dynamometamorphic striation. The main results of these studies are in [Gintov, 2005].
The studing of the tectonites and secondary structural textural elements (STE) (striation (migmatite, granitognesis), shcistosity (crystalline and shale), cleavage) (classification agree [Shevchuk et al., 2002, 2013; Shevchuk, Pavlov, 2003]) (Fig. $5 f-c$ ) were performed by the authors of this article. STE term we used in our article but it named fabric divided on the foliation and lineation in the English literature classification [Fossen, 2010].

Previously in the tectonophysical study of SP fault zone, not enough attention was paid to the rock fracturing of the crystalline basement. We determinated that the brittle fracturing forms clear structural paragenesis. It allows us to determinate the kinematics and stress-strain state of SP fault zone at late stages of tectogenesis when the rocks already were exhumated to the surface.

Processing and interpretation of field measurements of the STE of the rock fracturing were performed by structural-paragenetic method of tectonophysics for III-IV levels of depth [Stoyanov, 1977; Gintov, 2005] using the Stereonet program [Allmendinger et al., 2012; Cardozo, Allmendinger, 2013]. The planes of the STE are showed on stereograms by planes and poles on the upper hemisphere (Fig. 5). Cracks are showed on stereograms by poles, which are the intersection points of the normal to the plane of the crack and the upper hemisphere (Fig. 6).

Tectonophysical studies of the Sushchany-Perga fault zone. Tectonophysical studies were carried out on the outcrops of the river Ubort near villages: Zolnia (P. 1), Lopatichi (P. 2), Varvarivka (P. 3), Olevsk, (P. 4) Khmelivka (P. 5 and P. 6), Sushchany (P. 7), RudniaKhochynsk (P. 9), Khochyne (P. 10), MaidanKopyshchanskyj (P. 11), Tepenytsia (P. 12), and along the Perga River at the settlements of Perga (P. 8), Ustynivka (P.13) (see Fig. 1, 2 and Table 1). As mentioned above, the focus of the SP fault zone study was on the measurement of STE. Totally, the 113 measurements of striation, schistosity and cleavage were performed. It was possible only in 97 cases to establish azimuths and angles of their dips due to weathering of rocks. This study 


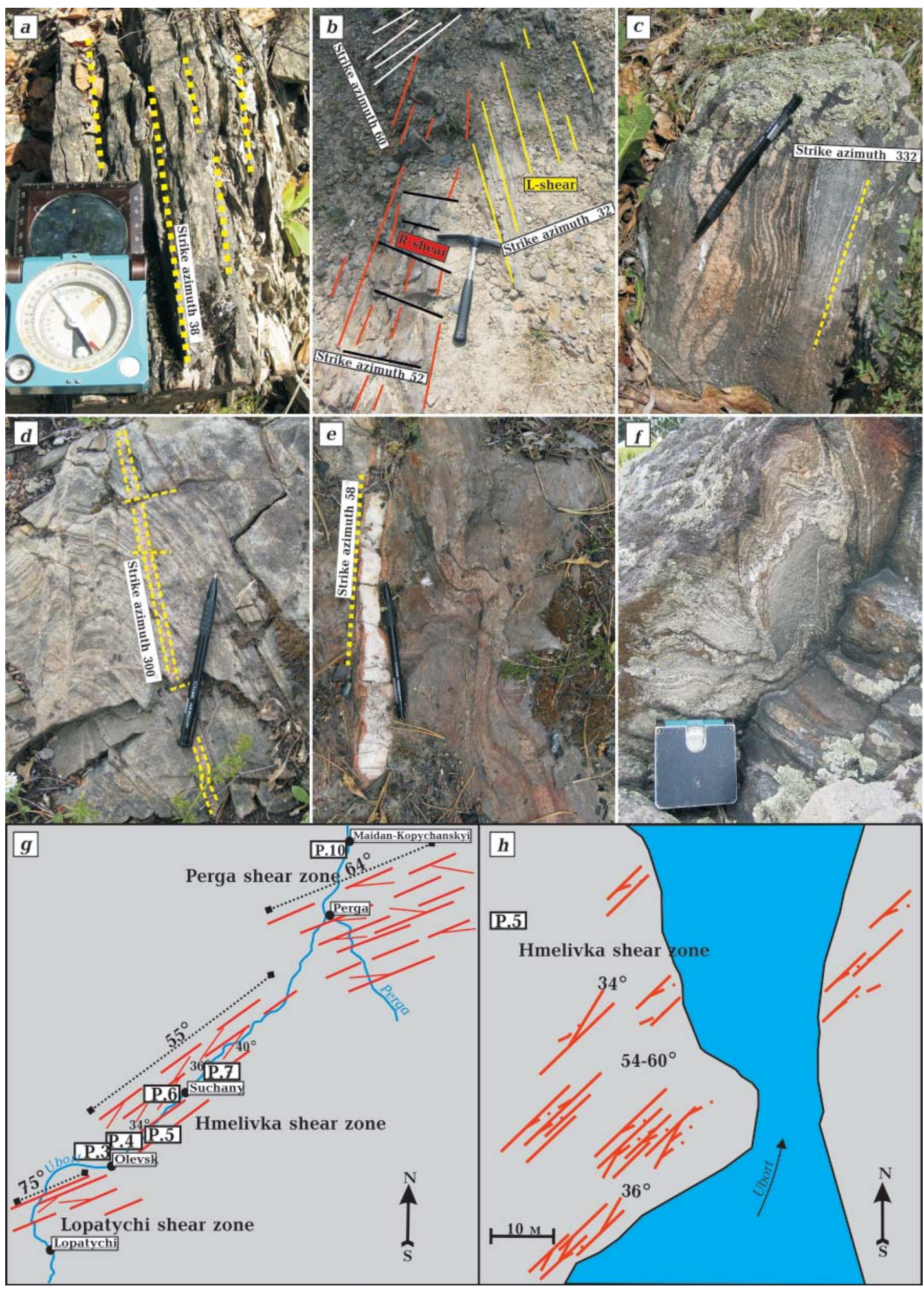

Fig. 5. Deformation structures in the rocks of the Sushchany-Perga fault zone [Mychak, Farfuliak, 2019]: $a$ - tectonic stratification of Osnytsk complex granitoids. The left side of the Ubort River near Sushchany (P.7); $b-$ fracturing of the Zhytomyr complex. The left side of the Ubort River near Khmelivka (P. 5); $c$ - migmatite zoning in the Zhytomyr complex granitoids between Khochyne (P. 10) and Maidan-Kopyshchanskyj (P. 11); $d$ - The gneiss fold is broken by granite vein in the horizontal area. The left side of the Ubort River near the Varvarivka (P. 3); $e$ - The quartz vein lies along the fold of the gneiss. The left side of the Ubort River near Khmelivka (P. 5); $f-$ Microfolding is situated in the vertical wall of the gneiss outlet. The left side of the Ubort River near Olevsk (P. 4); $g$, $h$ - tectonophysical scheme of orientation of the structural and textural elements within the Perga tectonic joint. 

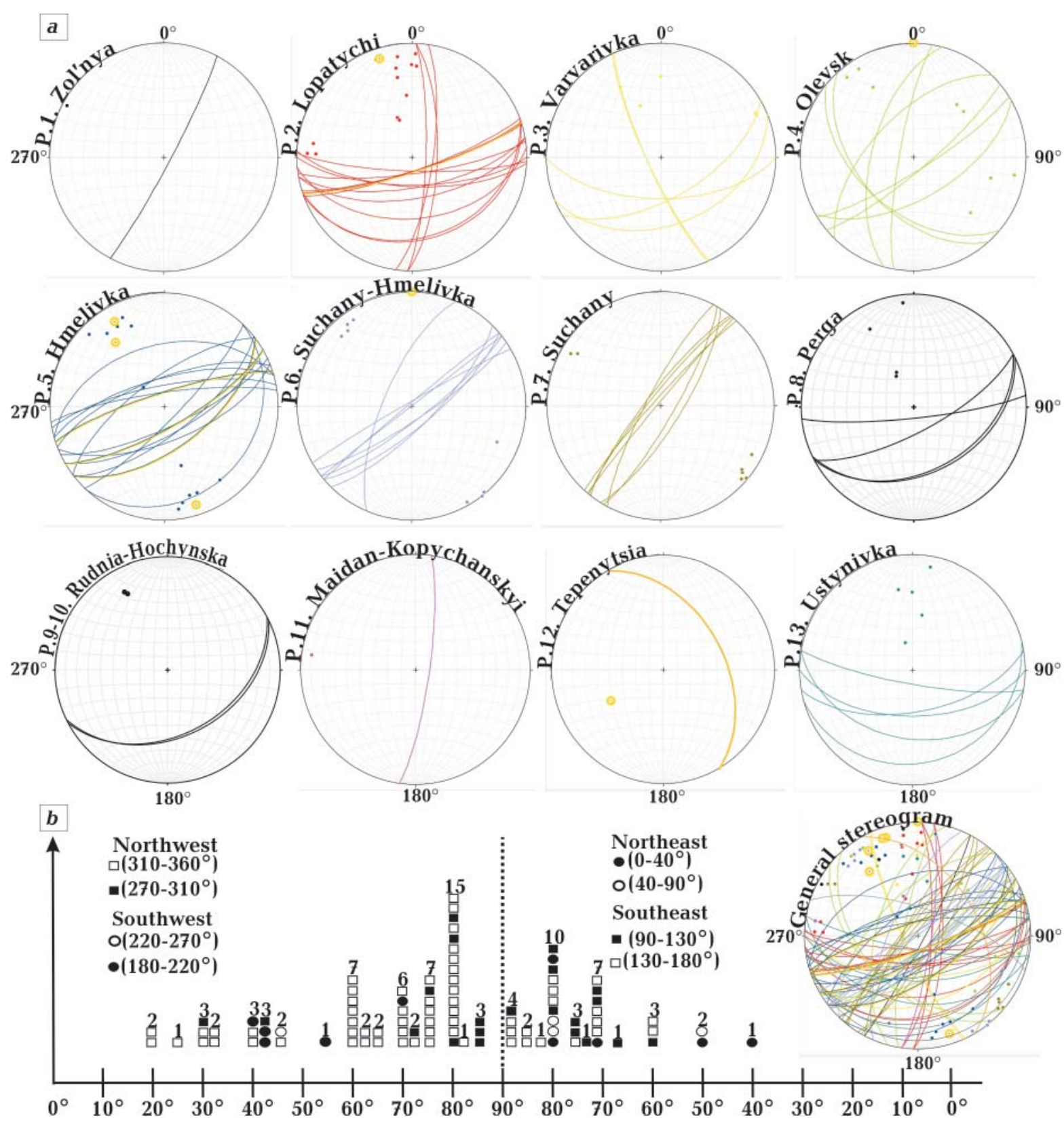

Fig. 6. Elements of planes (a) and histogram of azimuths and dip angles (b) of structural and textural elements of rocks within the studied area of the Sushchany-Perga fault zone. The numbers of points correspond to the areas in Figs. 1, 2, 5.

allowed to distinguish shear zones and their sequence and to reconstruct the stress-strain state of rocks. In the same area we carried out 462 measurements of brittle cracks strike and dipping.

It makes possible to determine kinematics and the stress-strain state of the SP fault zone for the later stages of tectogenesis. In addition to our own data we used previous field tectonophysical data of O.B. Gintov' for generalization in the context of our task.

Structura-and-textural elements of the Sushchany-Perga fault zone. The SP fault zone has clear structural and textural anisotropy due to our field tectonophysical study (Fig. 6). Stratification and mylonitization sometimes reach high intensity (Sushchsny village, Fig. 6, a), that was consider to be sedimentary bedding (the so-called «perga suite» [Gintov, 2005]). 
The dipping trend and angles of shale, migamite and granite-gneiss striation are shown in Fig. $6, a, b$ that in table 1. The majority of them (62 planes) is steeply dipping with angles $70-90^{\circ}$ and 34 planes dipping to the NW. The incline dipping $\left(20-60^{\circ}\right)$ is in $34 \%$ (35 measurements) cases and in $80 \%$ (28 measurements) cases of that dipping to the NW.

The multiphase development of SP fault zone was accompanied by the formation of differently oriented shear zones (see Fig. 7 and Table 2), which relative age was determined by the nature tucks in of the L and Rshear fractures.

The shear zones and deformation phases were identified in the order of decreasing age: Khmelivka - 140/88 (strike azimuth $50^{\circ}$ ), Sushchanska - 130/88 (strike azimuth $40^{\circ}$ ), Perga - 334/50 (strike azimuth $64^{\circ}$ ), RudniaKhochynsk - 345/42 (strike azimuth $64^{\circ}$ ),

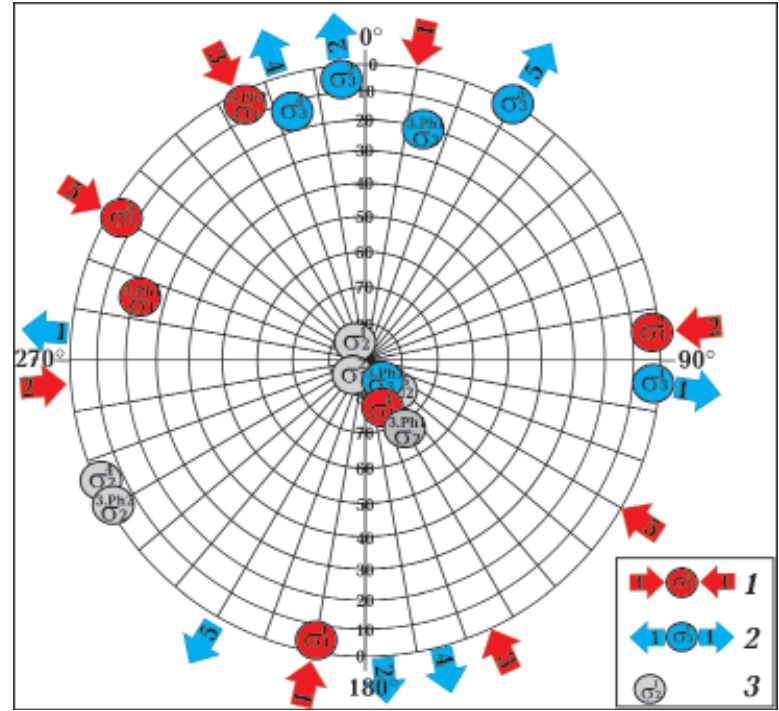

Fig. 7. The results of the inverse kinematic task for the Sushchany-Perga fault zone: 1 - Compression $\left(\sigma_{1}\right) ; 2$ - extension $\left(\sigma_{3}\right) ; 3$ - intermediate principal stress $\left(\sigma_{2}\right)$ and their superscript is stress strain deformation phases (Table 2).

\section{Ta b l e 1. Coordinates of the STE bedding in the Sushchany-Perga fault zone}

\begin{tabular}{|c|c|c|c|c|c|c|}
\hline \multirow{2}{*}{$\begin{array}{c}\text { Points } \\
\text { Fig. 1, } 2\end{array}$} & \multicolumn{2}{|c|}{ Coordinates } & \multirow{2}{*}{ Locality } & \multirow{2}{*}{$\begin{array}{c}\text { Strike azimuth } \\
\text { STE (average } \\
\text { value) }\end{array}$} & \multirow{2}{*}{$\begin{array}{c}\text { Dip azimuth } \\
\text { STE }\end{array}$} & \multirow{2}{*}{ Rocks } \\
\hline & Latitude & Longitude & & & & \\
\hline P. 1 & $51^{\circ} 05^{\prime} 02,5^{\prime \prime}$ & $27^{\circ} 31^{\prime} 0,3^{\prime \prime}$ & Zolnya & $20^{\circ}$ & NW & Osnytsk granites \\
\hline P. 2 & $51^{\circ} 09^{\prime} 47,5^{\prime \prime}$ & $27^{\circ} 32^{\prime} 41,4^{\prime \prime}$ & Lopatychi & $70-80^{\circ}\left(75^{\circ}\right)$ & NW & Osnytsk granites \\
\hline \multirow{2}{*}{ P. 3} & \multirow{2}{*}{$51^{\circ} 12^{\prime} 55,9^{\prime \prime}$} & \multirow{2}{*}{$27^{\circ} 35^{\prime} 17,6^{\prime \prime}$} & \multirow{2}{*}{ Varvarivka } & $60^{\circ}$ & NW & \multirow{2}{*}{$\begin{array}{l}\text { Granitoids of } \\
\text { the Zhytomyr complex }\end{array}$} \\
\hline & & & & $300^{\circ}$ & $\mathrm{NE}$ & \\
\hline \multirow{2}{*}{ P. 4} & \multirow{2}{*}{$51^{\circ} 14^{\prime} 11,3^{\prime \prime}$} & \multirow{2}{*}{$27^{\circ} 40^{\prime} 1,28^{\prime \prime}$} & \multirow{2}{*}{ Olevsk } & \multirow{2}{*}{$\begin{array}{c}50-60^{\circ} \\
\left(65^{\circ}\right)\end{array}$} & NW & \multirow{2}{*}{ Osnytsk granites } \\
\hline & & & & & $\mathrm{NE}$ & \\
\hline \multirow{2}{*}{ P. 5} & \multirow{2}{*}{$51^{\circ} 14^{\prime} 54,8^{\prime \prime}$} & \multirow{2}{*}{$27^{\circ} 40^{\prime} 59,9^{\prime \prime}$} & \multirow{2}{*}{ Hmelivka } & \multirow{2}{*}{$\begin{array}{c}50-60^{\circ} \\
\left(55^{\circ}\right)\end{array}$} & NW & \multirow{2}{*}{ Osnytsk granites } \\
\hline & & & & & $\mathrm{NE}$ & \\
\hline \multirow{2}{*}{ P. 6} & \multirow{2}{*}{$51^{\circ} 16^{\prime} 49,3^{\prime \prime}$} & \multirow{2}{*}{$27^{\circ} 43^{\prime} 57,7^{\prime \prime}$} & \multirow{2}{*}{$\begin{array}{l}\text { area Suchany- } \\
\text { Hmelivka }\end{array}$} & \multirow{2}{*}{$65^{\circ}$} & NW & \multirow{2}{*}{$\begin{array}{c}\text { Osnytsk granites; } \\
\text { Granitoids of } \\
\text { the Zhytomyr complex }\end{array}$} \\
\hline & & & & & $\mathrm{NE}$ & \\
\hline \multirow{2}{*}{ P. 7} & \multirow{2}{*}{$51^{\circ} 18^{\prime} 21,2^{\prime \prime}$} & \multirow{2}{*}{$27^{\circ} 45^{\prime} 48,6^{\prime \prime}$} & \multirow{2}{*}{ Suchany } & \multirow{2}{*}{$30-55^{\circ}$} & $\mathrm{NE}$ & \multirow{2}{*}{ Lvivkivsk granites } \\
\hline & & & & & NW & \\
\hline P. 8 & $51^{\circ} 23^{\prime} 46,0^{\prime \prime}$ & $27^{\circ} 53^{\prime} 28,6^{\prime \prime}$ & Perga & $64^{\circ} ; 84^{\circ}$ & NW & Perga granites \\
\hline P. 9 & $51^{\circ} 26^{\prime} 14,4^{\prime \prime}$ & $27^{\circ} 53^{\prime} 54,1^{\prime \prime}$ & $\begin{array}{c}\text { Rudnya-Ho- } \\
\text { chynska }\end{array}$ & $\begin{array}{c}62-70^{\circ} \\
\left(64^{\circ}\right)\end{array}$ & NW & Perga granites \\
\hline P. 10 & $51^{\circ} 27^{\prime} 59,2^{\prime \prime}$ & $27^{\circ} 52^{\prime} 51,6^{\prime \prime}$ & Hochyne & - & - & Perga granites \\
\hline P. 11 & $51^{\circ} 30^{\prime} 57,8^{\prime \prime}$ & $27^{\circ} 52^{\prime} 33,1^{\prime \prime}$ & $\begin{array}{c}\text { Maidan- } \\
\text { Kopychans-kyi }\end{array}$ & $12^{\circ}$ & $\mathrm{W}$ & $\begin{array}{l}\text { Granitoids of the Zhy- } \\
\text { tomyr complex }\end{array}$ \\
\hline P. 12 & $51^{\circ} 13^{\prime} 33.5 »$ & $27^{\circ} 41^{\prime} 44.6 »$ & Tepenytcia & $315^{\circ}$ & NW & Pink-gray granite \\
\hline P. 13 & $51^{\circ} 20^{\prime} 14.8 »$ & $27^{\circ} 56^{\prime} 1.7 »$ & Ustynivka & $75-80^{\circ}$ & NNW & Ustynivka granites \\
\hline
\end{tabular}


Lopatychska - 345/83 (strike azimuth $75^{\circ}$ ) [Gintov, 2005].

1. Khmelivka shear zone (P. 4-P. 7, see Fig. $4,5, d)$. This zone trends to the $\left(54-60^{\circ}\right)$ NE (see Fig. 5, d) with dip angle a 70 to $88^{\circ}$ NW (see Fig. 6 and Table 1). Such shears are found in the outcrops along the Ubort River on the Olevsk ' NW outskirt, as well as on the Khmelivka and Sushchany villages SW and N outskirts. Elementary shears are represented by mylonites and blastomylonites. Brittle displacements along the shears are not observed. There are left and right S-Z tucks under the shears. Elementary shears are combined into echeloned fault zone (see Fig. 5, e).

2. Sushchany shear zone (P. 1, P. 4-7, see Figs. 2, 5, d). This zone strikes in a NE direction at an angle of $40^{\circ}$ with a dip to the SE at an angle of $80-85^{\circ}$. The L-shears of this zone have the same elements as the axial plane. R-shears strike witn $34^{\circ}$ in a NE direction, dip- ping to a NW angle of $82^{\circ}$. It is established that along the shearing zone in the process of its formation there were left-slip — strike-slip movements.

3. Perga shear zone. This zone is represented by Perga (see P. 8, Fig. 4), Osnytsk (P. 6), Ustyniv (P. 13) granites. Prega granites are considered intrusive rocks and are genetically related to Korosten pluton [Sheremet, 2013]. The obtained dates for cirtolite $(1760 \pm 5 \mathrm{Ga}$ [Shcherbak et al., 2008]) confirm the affinity with this complex [Dubina, Kryvdik, 2014].

Two phases of the strains are defined in Perga shear zone. The first phase has strike from 58 to $64^{\circ}$ (see Fig. 5, 6, g) with a NW dip at an angle of $72^{\circ}$ and is L-shear. Their strike coincides with the strike of the axes of magnetic anomalies (see Fig. $4, b$ ) in the area of distribution of these shears. Shears are composed mainly of mylonites. There are right tucks in of the NE $84^{\circ}$ strike, at the $82^{\circ}$ angle

Ta b le 2. Deformation phases of the Sushchany-Perga fault zones according to the structura-textural elements

\begin{tabular}{|c|c|c|c|c|c|c|}
\hline \multirow[b]{2}{*}{ № } & \multirow{2}{*}{\multicolumn{2}{|c|}{ Phases }} & \multicolumn{3}{|c|}{ Axes of stress } & \multirow[b]{2}{*}{ Kinematics } \\
\hline & & & $\begin{array}{c}\sigma_{1} \\
\text { (compression) }\end{array}$ & $\begin{array}{c}\sigma_{3} \\
\text { (extension) }\end{array}$ & $\begin{array}{c}\sigma_{2} \\
\text { (intermediate } \\
\text { principal stress) }\end{array}$ & \\
\hline 1 & \multicolumn{2}{|c|}{ Hmelivka } & $185 / 02^{\circ}$ & $95 / 02^{\circ}$ & $330 / 88^{\circ}$ & Left-lateral strike-slip \\
\hline 2 & \multicolumn{2}{|c|}{ Suchany } & $85 / 05^{\circ}$ & $355 / 05^{\circ}$ & $220 / 85^{\circ}$ & Right-lateral strike-slip \\
\hline \multirow{2}{*}{3} & \multirow{2}{*}{ Perga } & Phase 1 & $286 / 20^{\circ}$ & $12 / 20^{\circ}$ & $150 / 70^{\circ}$ & Right-lateral strike-slip \\
\hline & & Phase 2 & $335 / 05^{\circ}$ & $140 / 85^{\circ}$ & $240 / 02^{\circ}$ & Thrust fault \\
\hline 4 & \multicolumn{2}{|c|}{ Rudnia-Hochynsk } & $150 / 78^{\circ}$ & $342 / 12^{\circ}$ & $246 / 02^{\circ}$ & Normal Downthrow fault \\
\hline 5 & \multicolumn{2}{|c|}{ Lopatychi } & $300 / 07^{\circ}$ & $30 / 02^{\circ}$ & $135 / 83^{\circ}$ & Right-lateral strike-slip \\
\hline
\end{tabular}
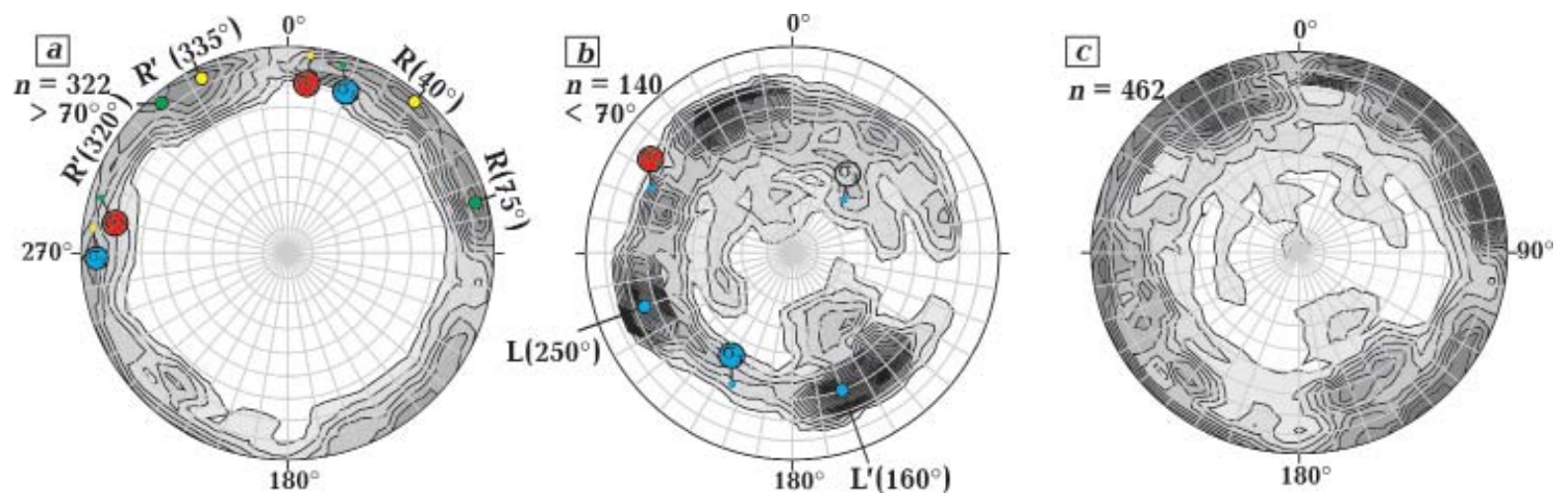

Fig. 8. Stereograms of elements of occurrence (dip azimuths) of rock cracks within the Sushchany-Perga fault zone: $a-$ subvertical dippig of the shears $\left(70-90^{\circ}\right) ; b-$ inclined cracks $\left(40-70^{\circ}\right) ; c-$ common stereogram of the dip cracks. 
of the dipping in the NW rhumbs under the shears. They were identified as R-shear, which corresponds to the right-lateral shear.

4. Rudnia-Khochynsk shear zone (P. 9, 10, see Fig. 2) morphologically is a downrtow with a gentle NW dipping at an angle of $40-42^{\circ}$ and has a strike of $64^{\circ}$. The area is represented by Perga granites, thin schistose, mylonites and cataclasites.

5. The Lopatychi shear zone (P. 2, see Fig. 2) is represented by the Osnytsk complex of granites and strikes in the NW rhumbs at an angle of $75^{\circ}$ with a dipping to the NW of $60-70^{\circ}$ (see Fig. 4, d). There are left and right S-Z tucks in at an angle of 37 and $21^{\circ}$ with a NW dipping at an angle of $45^{\circ}$ with a left type of displacement, under the shears.

After analysis of the inverse kinematic task (see Fig. 7 and Table 2), we can conclude that the Khmelivka and Sushchany phases of SP fault zone of strains are similar to the phases of formation of the Nemyriv and Khmilnyk fault zones. Therefore, these phases can be coresponding to the Nemyriv faulting stage. Similar [Gintov, 2005] Sushchany faulting phase is observed in both the Nemyriv and Khmilnyk fault zones. In the Khmelivka shear zone, Zhytomyr granites have been recycled into blastomylonites, mylonites and migmatites. In the Sushchany shear zone, Osnytsk granites are mylonitized.

The SP fault zone was quite active during the time of the interaction between Fennoskandia and Sarmatia at the Rudnia-Khochyno and Perga phases [Bogdanova et al., 1996, 2013]. Such interaction in the form of compression and tension, thrust and downthrow occurred during the Perga complex formation $(1.80-1.70 \mathrm{Ga})$ with increased fracturing, stratification or schistosity and propagation of STE.

The nature and conditions of the Sushchany-Perga fault zone fracturing. The crack systems of the shearing and rupturing (represented by granite and quartz reefs, pegmatites) are characteristic structural elements of the study area. In one case, they have the same elements of occurrence with STE and in another case they cross the rocks of the crystalline basement, including STE shear zones.
The kinematics of SP fault zone by fracturing is shown in Fig. 8. Cracks are often subvertical (70\%), although sometimes there are systems of inclined ruptures (30\%). The angles between the paragenetically linked cracks indicate the most frequent R-shear formation in the condition of the I-II levels depth. The study of the main systems of cracks of the SP fault zone allows us to assess the evolution of its stress-strain state in the context of the general history formation of the Volyn domain of the US in the Proterozoic stages.

According to the measurements of the subvertical cracks (Fig. 8, a) two stress fields are determinated:

$$
\mathrm{R}\left(40 / 86^{\circ}\right)-\mathrm{R}^{\prime}\left(335 / 86^{\circ}\right), \sigma_{1}-07 / 86, \sigma_{3}-
$$
277/86, $\sigma_{2}-\perp$, right-lateral shear;

$\mathrm{R}\left(75 / 85^{\circ}\right)-\mathrm{R}^{\prime}\left(320 / 85^{\circ}\right), \sigma_{1}-287 / 85$, $\sigma_{3}-17 / 86, \sigma_{2}-\perp$, left-lateral shear.

In accordance with measurements of the inclined cracks (Fig. 8, b), the stress field (L $\left(250 / 65^{\circ}\right)-\mathrm{L}^{\prime}\left(160 / 60^{\circ}\right), \Sigma_{1}-295 / 25, \sigma_{3}-$ $\left.207 / 30, \sigma_{2}-45 / 60\right)$ is close to the fifth deformation phase (Lopatychi). Most likely, this field began to form immediately after the last phase of STE.

Turning to the question of Ore-bearing Sushchany-Perga fault zone it should be noted [Nechaev et al., 2019] that the most number of deposits and ore occurrences of US minerals are associated with fault zones. Faults serve as channels for the entry into the upper layers of the platform covered of hydrogengas fluids and the exhalation of chemical elements in the form of free atoms and ions. The structures of the extension (rupture cracks) the most penetrating for upward flows in the fault zone are, then in decreasing order: Riedel shears and next L-shears. However it is proved [Nikolaevsky, 1982; Gintov, Isai, 1984] that in the process of plastic deformation of rocks in the fault zone, even during compression, there is dilatancy - loosening of the rock, which reaches a degree of one to several percent. This is clearly seen by gravimetric data, which indicate to the decompression of the earth's crust in fault zones.

The process of deposit formation and the nature of mineral ore formation are multistage ones and stretched over time. It is first 
of all related to the kinematic features of the Precambrian plate tectonic process, which is primarily due to the orientation of the fault zones during their initiation, as well as their stress-strain state during activations. The distribution area of metasomatitesis of great importance for the localization of ore fields and around the general mineral deposits as well as for localization in the hard blocks of the ancient basement.

As mentioned above, the SP fault zone was influenced by several phases of activation (like lateral shear and downthrow upthrow), especially in connection with the subduction-collision processes that occurred during the joining of the Fennoscandia and Sarmatia microcontinents.

In the area of intersection with the Central fault zone within the Perga joint, we have the Perga beryllium (genthelvin) deposit with gold ore, rare metal and sulphide mineralization, including Sn. The Yuriyivsky massif of titanium-bearing gabbroids, Yastrubets massif of syenites (comes from the Korosten pluton [Mitrokhin, 2011; Dubyna, Kryvdik, 2014]), Sushchany disthene deposit, as well as, placers and bed-rocks of the tin (cassiterite), tantalum-niobium ores are situated in the field of Perga granites. Scheelite skarns with superimposed sulfide and precious metal $(\mathrm{Ag}, \mathrm{Au})$ mineralization and other minerals are known in the area [Bogdanova et al., 2004; Kondratenko, Kostenko, 2015; Galetsky et al., 2016; Ponomarenko et al., 2017; Nechaev et al., 2019]. Molybdenum mineralization is located within the area of distribution of medium-coarse-grained leukogranites of the Ustynivka ore in the area of propagation [Kondratenko, Kostenko, 2016].

Discussion. The tectonic SP fault zone is a south-eastern boundary of the OsnytskMikashevichi volcanic-plutonic belt and is one of the frontal parts of the strike-slip structure, which was formed in the compression geodynamic conditions due to relaxation tectonic movements on the later stages of the two microplates of the Eastern European craton collision: Fennoscandia and Sarmatia (see Fig. 1). Modern deep seismic sounding data show the process of paleosubduction by
Fennoscandia under Sarmatia [Bogdanova et al., 2006].

The author [Gintov, 2019] substantiates the assumption of the existence of two paleosubductions of Fennoscandia under Sarmatia according to seismic and tectonophysical data and that the Suzhany-Perga fault zone was formed as a result of the second paleosubduction.

The authorsin [Ponomarenko et al., 2017] proved that components of rocks such as fluorine and lanthanides participated in the crystallization of fluorite of the Sushchany-Perga fault zone of the VD of the US, which have a mantle origin. This is one of the evidences that SP fault zone has a mantle origin.

That is, on the EUROBRIDGE 97 profile a reflector was found at depths of $45-80 \mathrm{~km}$, from the northern edge of the Prypiat trough to the middle of the Korosten pluton [Ilchenko, 2002; Thybo et al., 2003], which is the joint zone of Fennoscandia and Sarmatia plates.

Thus, along the PANCKAKE and EB'97 profile in the SP fault zone and adjacent areas the high velocities may represent modified lower crust, at least in part, by magmatic underplating or mafic intrusion, as interpreted in other locations worldwide [Yegorova et al., 2004; Bogdanova et al., 2004, 2006].

The results of interpretation presented in the work allowed to clarify that formation of the Sushchany-Perga fault zone continued during at least five phases of deformation. They were accompanied by the formation of differently oriented shear zones: Khmelivka, Sushchany, Perga, Rudnia-Khochin, Lopatychi, which belong to the Nemyriv stage of faulting $(\sim 1.99 \mathrm{Ga})$.

We have established that the development of thrust fault and normal down throwfault types hears, which took place in an environment of compression and extension, respectively, is associated with the formation period of the Perga granitoids complex (1.80$1.70 \mathrm{Ga})$. This alternation of the compression and extension condition sent ailed resulted in the ore occurrences and deposits formation.

Conclusions. The tectonophysical research of the SP fault zone of the Volyn Do- 
main of the western part of the US allows us identifying changes in the stress-strain state in space and time.

The formation of the SP fault zone occurred during at least five stages (five phases) of deformation according to structural/textural elements and three stages - according to jointing. It was accompanied by the formation of differently oriented shear zones, whose age has been determined using their structured relationship and near fault folding. The following shear zones and deformation phases are identified in the order of decreasing age: Khmelivka - 140/88 (numerator - dip azimuth, denominator - dip angle), Sushchany - 130/88, Perga - 334/50, Rudnia-Khochyno - 345/42, Lopatychi - 345/83.

The Khmelivka and Sushchany phases are

\section{Reference}

Allmendinger, R.W., Cardozo, N., \& Fisher, D. (2012). Structural geology algorithms: vectors and tensors. Cambridge University Press, $304 \mathrm{p}$.

Bogdanova, S.V., Gintov, O.B., Kurlovich, D.M., Lubnina, N.V., Nilsson, M.K., Orlyuk, M.I., Pashkevich, I.K., Shumlyanskyy, L.V., \& Starostenko, V.I. (2013). Late Palaeoproterozoic mafic dyking in the Ukrainian Shield of Volgo-Sarmatia caused by rotations during the assembly of supercontinent Columbia (Nuna). Lithos, 174, 196-216. https://doi.org/10.1016/j. lithos.2012.11.002.

Bogdanova, S., Gorbatschev, R., Grad, M., Guterch, A., Janik, T., Kozlovskaya, E., Motuza, G., Skridlaite, G., Starostenko, V., \& Taran, L. (2006). EUROBRIDGE: New insight into the geodynamic evolution of the East European Craton. In European Lithosphere Dynamics (pp. 599 - 628). Geol. Soc., London, Memoirs, 32.

Bogdanova, S.V., (1993). Segments of the East European Craton. In EUROPROBE in Jablonna 1991 (pp. 33-38). European Science Foundation, Polish Academy of Sciences.

Bogdanova, S.V., Bingen, B., Gorbatschev, R., Kheraskova, T.N., Kozlov, V.I., Puchkov, V.N., \& Volozh, Y.A. (2008). The East European Craton (Baltica) before and during the assembly of Rodinia. Precambrian Research, 160(1-2), 23-45. https://doi.org/10.1016/j.precamres.2007.04.024. similar to the phases of formation of the Nemyriv and Khmilnyk fault zones of the Nemyriv stage. These shear zones cut and deform both Osnytsa( 1.99 Ga) and Zhytomyr granites (2.06-2.08 Ga). Thus, their age, as well as the whole Nemirov stage, is not earlier than about 1.99 Ga. The Rudnia-Khochyno and Perga phases are a result of the SP fault zone activation at the time of the interaction between Fennoskandia and Sarmatia microcontinents. We determined that compression and extension interaction took place during the formation of the Perga complex (1.80$1.70 \mathrm{Ga})$.

The next step should be a detailed geological and geophysical study of other parts of the Sushchany-Perga fault zone within the Ukrainian Shield and its slope.

Bogdanova, S.V., Pashkevich, I.K., Buryanov, V.B., Makarenko, I.B., Orlyuk, M.I., Skobelev, V.M., Starostenko, V.I., \& Legostaeva, O.V. (2004). The 1.80-1.74 Ga gabbro-anorthosite-rapakivi Korosten Pluton in the NW Ukrainian Shield: a 3-D geophysical reconstruction of deep structure. Tectonophysics, 381(1-4), 5-27. https:// doi.org/10.1016/j.tecto.2003.10.023.

Bogdanova, S.V., Pashkevich, I.K., Gorbatschev, R., \& Orlyuk, M.I. (1996). Riphean rifting and mojor Palaeoproterozoic crustal boundaries in the basement of the East European Craton: geology and geophysics. Tectonophysics, 268(1-4), 1-21. https://doi.org/10.1016/S00401951(96)00232-6.

Cardozo, N., \& Allmendinger, R.W. (2013). Spherical projections with OSXStereonet. Computers \& Geosciences, 51, 193-205. https://doi. org/10.1016/j.cageo.2012.07.021.

Chekunov, A.V. (Ed.). (1989). Lithosphere of the Central and Eastern Europe. East European platform. Kiev: Naukova Dumka, 180 p. (in Russian).

Dubina, O.V., \& Kryvdik, S.G. (2014). Geochemical and petrological features of the alkaline granites of the Ukrainian Shield. Heolohichnyy Zhurnal, (3), 83-94 (in Ukrainian).

Entin, V.A., Shimkiv, L.M., Nechayeva, T.S., Dzyuba, B.M., Gintov. O.B., Pashkevich, I.K., \& Kra- 
sovskiy, S.S. (2002). Preparation of the geophysical basis of the tectonic map of Ukraine of scale 1:100 000. Kyiv: Geoinform of Ukraine, 55 p. (in Ukrainian).

Fossen, H. (2010). Structural geology. Cambridge Univer. Pres., 463 p. https://doi.org/10.1017/ CBO9780511777806.

Galetsky, L.S., Naumenko, U.Z., \& Chernienko, N.M. (2016). The main types of ore-bearing structures of Ukraine. Mineralni resursy Ukrayiny, (4), 12-19 (in Ukrainian).

Gintov, O.B. (2005). Field tectonophysics and its application in the study of deformations of the earth's crust in Ukraine. Kiev: Feniks, 572 p. (in Russian).

Gintov, O.B. (2014). Periodization scheme of the stages of fault formation in the earth's crust of the Ukrainian Shield - new data and consequences. Geofizicheskiy Zhurnal, 36(1), 3-18 https://doi.org/10.24028/gzh.0203-3100. v36i1.2014.116145 (in Russian).

Gintov, O.B. (2019). Plate-plume tectonics as an integrated mechanism of geodynamic development of the tectonosphere of Ukraine and adjacent regions. Geofizicheskiy Zhurnal, 41(6), 3-34. https://doi.org/10.24028/gzh.0203-3100. v41i6.2019.190064 (in Russian).

Gintov, O.B., \& Pashkevich, I.K. (2010). Tectonophysical analysis and geodynamic interpretation of a three-dimensional geophysical model of the Ukrainian Shield. Geofizicheskiy Zhurnal, 32(2), 3-18 (in Russian).

Gintov, O.B., Entin, V.A., \& Mychak, S.V. (2017). On plotting the Scheme of fracture-megablock tectonics of the Ukrainian Shield in a scale 1:500 000. Geofizicheskiy Zhurnal, 39(5), 63-82. https://doi.org/10.24028/gzh.02033100.v39i5.2017.112340 (in Ukrainian).

Gintov, O.B., \& Isai, V.M., (1984). Some regularities of fault formation and methods of morphokinematic analysis shear faults. Geofizicheskiy Zhurnal, 6(4), 3-14 (in Russian).

Gintov, O.B., Orlyuk, M.I., Entin, V.A., Pashkevich, I.K., Michak, S.V., Bakarzhina, M.I., Shimkiv, L.M., \& Marchenko, A.V. (2018). The structure of the Western and Central parts of the Ukrainian schield. Controversial issues. Geofizicheskiy Zhurnal, 40(6), 3-29. https://doi. org/10.24028/gzh.0203-3100.v40i6.2018.151000 (in Ukrainian).

Ilchenko, T.V. (1985). Methodology for determining the velocity model from the system of profile travelgraphs of waves in the GSZ. Geofizicheskiy Zhurnal, 7(1), 40-45 (in Russian).

Ilchenko, T.V. (2002). The results of studies by the DSS method along the EUROBRIDGE-97 geotranssect. Geofizicheskiy Zhurnal, 24(3), 36-50 (in Russian).

Kondratenko, P.A., \& Kostenko, M.M. (2015). Stanniferous of tectonic and metasomatic Suschano-Perzhanska zone (Ukrainian shield) is considered. Zbirnyk naukovykh prats UkrDHRI, (2), 22-39 (in Ukrainian).

Kondratenko, P.A., \& Kostenko, M.M. (2016). Regularities of localization and searching criterias of molybdenum mineralization within Ustynivka ore-bearing fields (Volyn block of Ukrainian shield). Mineral'ni resursy Ukrayiny, (2), 8-16 (in Ukrainian).

Kostenko, N.V. (2010). About the warehouse and granite complexes of the Volinsky megablock of the Ukrainian Shield based on the results of the interpretation of petrogeochemical donations. In Theoretical and applied aspects of geoinformatics: Collection of scientific works (pp. 173-183). Kyiv: LCC «Karbon- Servis» (in Ukrainian).

Krylov, N.A. (1988). Map of discontinuities and main lineaments of the south-west of the USSR (using space survey materials). 1:1000 000. Kiev: Publication of the USSR Ministry of Geology, 4 p. (in Russian).

Lysynchuk, D., Farfuliak, L., Kolomiyets, K., \& Kolomiyets, O. (2020). Seismic tomographic model along the geotraverse VI profile. XIXth International Conference "Geoinformatics: Theoretical and Applied Aspects» 11-14 May 2020 Kyiv, Ukraine.

Lysynchuk, D., Farfuliak, L., Kolomiyets, K., \& Kolomiyets, O. (2019). Reconstruction of seismic DSS crosssection of the VI geotravers and detaling of velocity characteristics of the earth crust in the gravity Bandura srtucture. 18th International Conference on Geoinformatics Theoretical and Applied Aspects. https://doi. org/10.3997/2214-4609.201902114. 
Metalidi, S.V., \& Nechaev, S.V. (1983). SushanoPerzhansk zone (geology, mineralogy, ore content). Kiev: Naukova Dumka, 136 p. (in Russian).

Mychak, S.V. (2015). Kinematics of formation of the western and central parts of the Ukrainian shield between 2.02-2.05 Ga ago. Geofizicheskiy Zhurnal, 37(1), 89-99. https://doi. org/10.24028/gzh.0203-3100.v37i1.2015.111327 (in Russian).

Mychak, S.V. (2016). Geodynamic development of the Ukrainian shield and the formation of mineral deposits according to geophysical and geochronological studies. Visnyk NAN Ukrayiny, (6), 77-85. https://doi:10.15407/ visn2016.06.077 (in Ukrainian).

Mychak, S.V., \& Farfuliak, L.V. (2019). Kinematic of the Sushcano-Perzhansk fault zone. In Ideas and innovations in Geosciences: Proc. of the VIII Ukrainian Young Scientific Conference, Kyiv, April 10-12, 2019 (pp. 68-69). Kyiv.

Nechaev, S.V., Gintov, O.B., \& Mychak, S.V. (2019). On the relation between the rare-earth - raremetal and gold ore mineralization and faultblock tectonics of the Ukrainian Shield. 1 Geofizicheskiy Zhurnal, 41(6), 3-32. https://doi. org/10.24028/gzh.0203-3100.v41i1.2019.158861 (in Russian).

Nikolaevsky, V.N. (1982). Earth's crust. Dilatancy and earthquakes. Earthquake hearth mechanics. Moscow, Mir. 217 p. (in Russian).

Ponomarenko, O.M., Voznyak, D.K., Samchuk, A.I., \& Belskyi, V.M. (2017). To the origin of the fluorite of the Sushchany-Perga ore zone (Ukrainian Shield). Dopovidi NAN Ukrayiny, (11), 52-58. doi.org/10.15407/dopovidi2017.11.052 (in Ukrainian).

Romanyuk, L.S. (2013). Geological structural position of the perzhan rare-metal district. Heolohichnyy Zhurnal, (2), 37-42 (in Ukrainian).

Scherbak, N.P., \& Volodin, D.F. (Ed.). (1984). Geological map of Precambrian formations of the Ukrainian Shield at a scale of 1:1000 000. Kiev: Mingeo USSR (in Russian).

Shcherbak, N.P., Artemenko, G.V., Lesnaya, I.M., Ponomarenko, A.N., \& Shumlyansky, L.V. (2008). Geochronology of the Early Precambrian of the Ukrainian Shield. Proterozoic. Kiev: Naukova Dumka, 240 p. (in Russian).
Shcherbak, N.P., Skobelev, V.M., \& Stepanyuk, L.M. (1998). Geological structure and age of the Precambrian Ukrainian Shield along the EUROBRIDGE Transect. Geofizicheskiy Zhurnal, 20(4), 105-107.

Sheremet, E.M. (2013). Petrology, geophysics and ore content of rare-metal granites of the Priazovie (Ukrainian shield). Donetsk: Noulidzh, 214 p. (in Russian).

Shevchuk, V.V. Lavrenyuk, M.V., \& Kravchenko, D.V. (2013). Fundamentals of Structural Analysis. Kyiv: VPC «Kiev University», 287 p. (in Ukrainian).

Shevchuk, V.V., \& Pavlov, G.G. (2003). Tectonophysical conditions for the formation of crystalline schistosity. Geofizicheskiy Zhurnal, 37(5), 76 -83 (in Russian).

Shevchuk, V.V., Kuz, I.S., \& Yurchishin, A.S. (2002). Tectonophysical bases of structural analysis. Lviv: Publication of Ivan Franko National University of Lviv, 124 p. (in Ukrainian).

Sollogub, V.B. (1986). Lithosphere of Ukraine. Kiev: Naukova Dumka, 184 p. (in Russian).

Sollogub, V.B. (Ed.). (1988). Lithosphere of Central and Eastern Europe. Geotraverse IV, VI, VIII (pp.127-165). Kiev: Naukova Dumka(in Russian).

Sollogub, V.B., Chekunov, A.V., \& Kaluzhnaya, L.T. (1988). Lithosphere structure along the geotraverse II. In Lithosphere of Central and East Europe. Geotraverse I, II, V. (63 pp.). Kiev: Naukova Dumka (in Russian).

Starostenko, V., Janik, T., Yegorova, T., Czuba, W., Środa, P., Lysynchuk, D., Aizberg, R., Garetsky, R., Karataev, G., Gribik, Y., Farfuliak, L., Kolomiyets, K., Omelchenko, V., Komminaho, K., Tiira, T., Gryn, D., Guterch, A., Legostaeva, O., Thybo, H., \& Tolkunov, A. (2018). Lithospheric structure along wide-angle seismic profile GEORIFT 2013 in Pripyat-DnieperDonets Basin (Belarus and Ukraine). Geophysical Journal International, 212(3), 1932-1962. https://doi.org/10.1093/gji/ggx509.

Starostenko, V., Janik, T., Kolomiyets, K., Czuba, W., Środa, P., Lysynchuk, D., Grad, M., Kovacs, I., Stephenson, R., Thybo, H., Artemieva, I.M., Omelchenko, V., Gintov, O., Kutas, R., Gryn, D., Guterch, A., Hegedüs, E., Komminaho, K., Legostaeva, O., Tiira, T., \& Tolkunov, A. (2013). Seismic velocity model of the crust and 
upper mantle along profile PANCAKE across the Carpathians between the Pannonian Basin and the East European Craton. Tectonophys ics, 608, 1049-1072. https://doi.org/10.1016/j. tecto.2013.07.008.

Stoyanov, S.S. (1977). The mechanism of formation of rupture zones. Moscow: Nedra, 144 p. (in Russian).

The creation of a complex trivial geophysical model of the lithosphere in connection with magmatism, tectonics, and the establishment of the corny copalins of the Ukrainian Shield. - Scientific call to the Institute of Geophysics of the National Academy of Sciences of Ukraine. (2006). Kiev, Ukrgeolfond, 515 p. (in Russian).

Thybo, H., Janik, T., Omelchenko, V.D., Grad, M., Garetsky, R.G., Belinsky, A.A., Karatayev, G.I., Zlotski, G., Knudsen, M.E., Sand, R., Ylini- emi, J., Tiira, T., Luosto, U., Komminaho, K., Giese, R., Guterch, A., Lund, C.-E., Lysynchuk, D.V., Kharitonov, O.M., Ilchenko, T., Skobelev, V.M., \& Doody, J.J. (2003). Upper lithospheric seismic velocity structure across the Pripyat Trough and the Ukrainian Shield along the EUROBRIDGE'97 profile. Tectonophysics, 371(1-4), 41-79. https://doi. org/10.1016/S0040-1951(03)00200-2.

Yegorova, T.P., Starostenko, V.I., Kozlenko, V.G., \& Yliniem, J. (2004). Lithosphere structure of the Ukrainian Shield and Pripyat Trough in the region of EUROBRIDGE-97 (Ukraine and Belarus) from gravity modeling. Tectonophys iCs, 381, 29-59. https://doi.org/10.1016/j.tecto.2002.06.003.

Mitrokhin, A.V. (2011). Anothosite-rapakivi-granite association of Ukrainian Shield (geology, composition and origin). Extended abstract of Doctorфs thesis. Kyiv, 36 p. (in Ukrainian).

\title{
Внутреннее строение и кинематика Сущано-Пержанской зоны разломов Украинского щита по результатам тектонофизических исследований
}

\author{
С.В. Мычак, А.В. Фарфуляк, 2021
}

\author{
Институт геофизики им. С.И. Субботина НАН Украины, Киев, Украина
}

С целью выяснения внутреннего строения и кинематики Сущано-Пержанской зоны разломов Волынского мегаблока Украинского щита проведены полевые тектонофизические измерения в бассейне верхнего течения р. Уборть по маршруту Зольня-Майдан-Копищенский. Проведено изучение трещиноватости и структурнотекстурных элементов горных пород структурно-парагенетическим методом тектонофизики с учетом глубины их формирования. По результатам интерпретации установлено, что формирование Сущано-Пержанской зоны разломов продолжалось в течение не менее пяти фаз и сопровождалось образованием соответствующих различно ориентированных зон скалывания: Хмелевской, Сущанской, Пержанской, Рудня-Хочинской, Лопатичской. Фазы формирования Хмелевской и Сущанской зон скалывания аналогичны по простиранию Немировской и Хмельникской зонам разломов Украинского щита, которые сформировались в немировский этап разломообразования ( 1,9 млрд лет). Рудня-Хочинская и Пержанская фазы связаны с активизацией Сущано-Пержанской зоны разломов во время взаимодействия микроплит Фенноскандии и Сарматии. Установлено, что с периодом формирования комплекса пержанских гранитоидов (1,80-1,70 млрд лет) связано развитие разрывов надвигового и сбросового типов, которые происходили в обстановке сжатия и растяжения соответственно. Такое чередование обстановок сжатия и растяжения повлекло за собой образование рудопроявлений в пределах Пержанского тектонического узла. Аанное исследование установило, что Сущано-Пержанская зона разлома возникла в позднем палеопротерозое на немировском этапе разломообразования одновременно 
с другими разломными зонами Украинского щита (Горинской, Ауцкой, Тетеревской и Немировской) в результате сочленения микроплит Фенноскандии и Сарматии.

Ключовые слова: Украинский щит, Сущано-Пержанская зона разломов, Пержанский тектонический узел, структурно-текстурные элементы, деформации, поля напряжений.

\title{
Внутрішня будова і кінематика Сущано-Пержанської зони розломів Українського щита за результатами тектонофізичних досліджень
}

\author{
С.В. Мичак, А.В. Фарфуляк, 2021
}

Інститут геофізики ім. С.І. Субботіна НАН України, Київ, Україна

\begin{abstract}
З метою визначення внутрішньої будови і кінематики Сущано-Пержанської зони розломів Волинського мегаблока Українського щита виконано польові тектонофізичні дослідження в басейні верхньої течії р. Уборть за маршрутом Зольня-Майдан-Копищенський. Проведено вивчення тріщинуватості і структурно-текстурних елементів гірських порід структурно-парагенетичним методом тектонофізики 3 урахуванням глибини їх фрормування. За результатами інтерпретації встановлено, що формування Сущано-Пержанської зони розломів тривало протягом не менше п'яти фраз і супроводжувалося утворенням відповідних різноорієнтованих зон сколювання: Хмелівської, Сущанської, Пержанської, Рудня-Хочинської, лопатичівської. Хмелівська та Сущанська зони сколювання аналогічні за простяганням Немирівській та Хмільницькій зонам розломів Українського щита, які сформувалися в немирівський етап розломоутворення ( 1,9 млрд років). Рудня-Хочинська і Пержанська фази пов' язані з активізацією Сущано-Пержанської зони розломів під час взаємодії мікроплит Фенноскандії та Сарматії. Встановлено, що з періодом формування комплексу пержанських гранітоїдів (1,80-1,70 млрд років) пов'язаний розвиток розривів насувного і скидового типів, що відбувались в обстановці стиснення і розтягу відповідно. Таке чергування ситуацій стиснення і розтягу спричинило утворення рудопроявів в межах Пержанського тектонічного вузла. Встановлено, що СущаноПержанська зона розломів виникла в пізньому палеопротерозої на Немирівському етапі розломоутворення одночасно з іншими розломними зонами Українського щита (Горинською, Ауцькою, Тетерівською і Немирівською) в результаті зчленування мікроплит Фенноскандії та Сарматії.

Ключові слова: Український щит, Сущано-Пержанська зона розломів, Пержанський тектонічний вузол, структурно-текстурні елементи, деформації, поля напруг.
\end{abstract}

